\title{
MEDIA SOSIAL INSTAGRAM SEBAGAI SARANA PROMOSI UNTUK MENINGKATKAN MINAT BELI KONSUMEN
}

\author{
Deru R. Indika* dan Cindy Jovita* \\ deru.indika@unpad.ac.id
}

\begin{abstract}
The speed of internet access and the rapid growth of the smartphone industry makes it easier for people to get information. In the field of marketing, this affects how the promotion is done. The use of social media which is actually means for social interaction between online individuals becomes commonly used by companies as a tool for promotion including in the tourism industry. One of the social media that is often used is Instagram, an application that allows users to share photos and pictures along with short messages with other users. This study discussed how Instagram as a social media can affect consumer purchase intention toward a tourist destination. The subject of research is Floating Market located in Lembang, Bandung, West Java. The results showed that information delivered through Instagram was effective in increasing consumer purchase intention up to $50.2 \%$
\end{abstract}

Keywords: social media, instagram, promotion, purchase intention.

\section{Pendahuluan}

Bermunculannya berbagai aplikasi media sosial ini menimbulkan peluang bagi masyarakat dalam melakukan suatu usaha. Peluang terhadap media sosial tidak berhenti hanya pada usaha produk. Usaha jasa maupun pariwisata juga mulai menggunakan media sosial sebagai salah satu sarana untuk menarik perhatian masyarakat untuk menggunakan atau mendatangi destinasi objek wisatanya. Pada umumnya objek wisata menggunakan media sosial untuk menarik pengunjung dan memberikan informasi-informasi terkait dengan event-event yang akan diadakan kepada masyarakat. Pemanfaatan social media dapat berimbas positif bagi pencitraan obyek atau destinasi wisata (Ellya, 2015).

Penggunaan media sosial digunakan oleh masyarakat dalam melakukan banyak aktivitas mulai dari entertainment, melakukan bisnis, mencari info atau aktivitas lainnya. Pengguna internet aktif di Indonesia per Januari 2016 mencapai 88.1 juta orang dan

* Fakultas Ekonomi dan Bisnis, Universitas Padjadjaran, Bandung. 
79 juta di antaranya merupakan pengguna media sosial yang aktif (Balea, 2016). Instagram sebagai salah satu media sosial populer di Indonesia berada di peringkat kedelapan dengan pengguna mencapai $10 \%$. Berdasarkan sumber e-marketer.com (2017), penggunaan instagram di Indonesia bagi pengguna dengan usia 16-35 tahun, melakukan posting foto-foto saat travelling mencapai $48.4 \%$ (peringkat ketiga). Di Indonesia, jumlah pengguna instagram aktif mencapai 22 juta orang. Adapun dengan persebaran demografi pengguna instagram 18-29 tahun memiliki penggunaan terbesar yaitu $83 \%$. Namun 18\% dari mereka yang berumur 30-49 tahun dan 6\% dari umur 50-64 tahun juga menggunakan instagram. Berdasarkan data tersebut, maka instagram merupakan salah satu media yang potensial untuk digunakan sebagai media promosi.

Floating Market, salah satu destinasi wisata populer di daerah Bandung Jawa Barat, menerapkan sisteminformasi berbasis digital marketing dan salah satu media digital marketing yang baru diluncurkan oleh Floating Market adalah melalui instagram. Instagram Floating Market dapat diakses menggunakan aplikasi instagram dengan domain akun @floating.market.lembang. Akun official instagram Floating Market digunakan untuk mempromosikan event dan untuk menyebarkan testimoni para pengunjungyang telah mengunjungi Floating Market guna menarik wisatawan yang lebih banyak lagi. Respon pasar menunjukkan bahwa jumlah pengunjung terus meningkat. Pada weekdays per harinya mencapai 2.0004.000 pengunjung sedangkan weekend mencapai 10.000-12.000 pengunjung (Negoro, 2015). Floating Market bisa memiliki omset sebesar Rp5 milyar untuk tiap bulannya. Hal ini menunjukkan bahwa Floating Market merupakan salah satu tempat wisata paling sering dikunjungi wisatawan saat ke kota Bandung.

Pengelolaan media sosial yang baik secara logis akan menarik minat pengunjung untuk datang.Berdasarkanfaktadiatasdisimpulkan bahwa penggunaan media sosial instagram dapat menarik pengunjung Floating Market. Pertanyaannya, apakah penggunaan instagram yang dilakukan efektif atau tidak terhadap minat beli pengunjung, di mana dirumuskan hipotesis sebagai berikut:

HO : bO : tidak terdapat pengaruh media sosial instagram terhadap minat beli konsumen.

H1 : b1 : terdapat pengaruh media sosial instagram terhadap minat beli konsumen.

\section{Tinjauan Pustaka}

Komunikasi pemasaran sebagai cara perusahaan dalam menginformasikan, mengajak, dan mengingatkan konsumen baik secara langsung maupun tidak langsung mengenai suatu produk atau brand yang dijualnya (Kotler \& Keller, 2016). Komunikasi pemasaran merupakan caracara yang dilakukan perusahaan untuk dapat berinteraksi baik dengan pihak-pihak internal perusahaan (karyawan) maupun eksternal (konsumen, pemerintah, pesaing, dll) dengan tujuan meningkatkan penjualan dan menjaga citra perusahaan. Salah satu bauran promosi yang digunakan perusahaan adalah media sosial.

Online and social media marketing menurut Kotler dan Keller (2016) adalah "online activites and programs designes to engage customers or prospects and directly or indirectly raise awareness, improve image, or elicit sales of products and services". Media sosial merupakan suatu aktivitas komunikasi pemasaran yang menggunakan media elektronik (online) dalam menarik konsumen atau perusahaan dalam berbagai bentuk (gambar, tulisan, dll) untuk meningkatkan kesadaran, citra perusahaan, dan untuk meningkatkan penjualan.

Trusov (dalam Kshetri dan Jha, 2016) mengatakan bahwa WOM elektronik dan iklan 
melalui media sosial membantu pemasar dalam menarik konsumen dengan harga yang rendah dan dalam hitungan waktu yang lebih cepat ditambah dengan review konsumen yang membantu menarik konsumen. WOM atau penggunaan media elektronik terhadap suatu brand merupakan suatu komunikasi yang menyampaikan informasi mengenai pemasok dan penggunaan produk kepada konsumen melalui online shopping menggunakan teknologi berbasis internet seperti facebook, twitter, instagram, dan berbagai media sosial lainnya (Kshetri dan Jha, 2016). Media sosial merupakan jaringan teknologi yang digunakan untuk menciptakan berita melalui pengguna internet dan mengkomunikasikan serta mendiseminasikan informasi, sedangkan pemasaran media sosial merupakan suatu jenis model pemasaran internet untuk mencapai tujuan pemasaran dengan berpartisipasi dalam lingkup jaringan media sosial (Maoyan, 2014).

Penyampaian komunikasi pemasaran melalui media sosial dinilai melalui 4C, yaitu context, communication, collaboration, dan connection(Hauer (2010) dalam Arief dan Millianyani, 2015). Context adalah "how we frame our stories" yaitu cara bagaimana seseorang membentuk suatu cerita melalui penggunaan bahasa dan isi pesan. Communication adalah "the practice of sharing our sharing story as well as listening, responding, and growing," yaitu cara bagaimana berbagi cerita membuat seseorang mendengar, merespon, dan tumbuh sehingga orang menjadi nyaman dan pesan tersampaikan kepada orang yang dituju. Collaboration adalah "working together to make things better and more efficient and effective". Kerja sama yang dimaksud adalah kerja sama antara akun atau perusahaan dengan pengguna media sosial yang bertujuan membuat hal menjadi lebih baik, lebih efisien, dan lebih efektif. Connection adalah "the relationship we forge and maintain" yaitu cara bagaimana mempertahankandanterusmengembangkan hubungan yang telah dilakukan.

Tujuan komunikasi pemasaran termasuk melalui media sosial adalah untuk menumbuhkan minat beli konsumen. Minat beli menurut Kwek (2010) dalam Setiawan (2015), menyatakan bahwa minat beli dapat diklasifikasikan sebagai bagian dari perilaku kognitif konsumen mengenai niat konsumen dalam membeli suatu brand. Hal ini sejalan dengan pernyataan Lefa dan Laroche (2006) dalam Setiawan(2015), yang mengatakan bahwa minat merupakan salah satu penilaian mengenai individu yang ingin membeli merek tertentu. Madahi dan Sukati (2012) juga mengatakan bahwa minat beli terjadi ketika seseorang membutuhkan produk tertentu setelah melakukan evaluasi atau mempersepsikan produk tersebut apakah layak atau tidak untuk dibeli.

Pengukuran efektivitas komunikasi pemasaran dapat dilihat pada model respon konsumen akan promosi yang dilakukan perusahaan, model AIDA (Attention, Interest, Desire, Action). Model AIDA (Vliet, 2014) terdiri atas 4 tahapan. Attention merupakan tahap pertama dari hirarki AIDA. Pada tahap attention, konsumen mulai timbul kesadarannya terhadap suatu produk sebelum terjadinya keputusan pembelian. Perhatian ini dapat diciptakan melalui warna, suara, gambar, artis, slogan, atau symbol-simbol lainnya. Tahap selanjutnya adalah interest. Ketika perhatian sudah tertuju terhadap suatu produk, maka muncul ketertarikan terhadap produk. Ketertarikan ini di dapat setelah konsumen mendapatkan sesuatu yang menurutnya unik. Tahap ketiga yaitu desire. Desire adalah tahapan memberikan penawaran yang menimbulkan keinginan atau hasrat konsumen untuk membeli suatu produk. Tahap terakhir adalah action yaitu tahap dimana konsumen sudah mengambil tindakan untuk mulai melakukan pembelian terhadap produk. Jika dihubungkan dengan minat beli dapat di- 
katakan bahwa minat beli merupakan suatu aktivitas yang dilakukan konsumen dalam menilai suatu produk sebelum melakukan keputusan pembelian. Pada model AIDA, minat beli berada pada tiga tahap pertama yaitu Attention, Interest, dan Desire.

Pemasaran melalui media sosial akan memengaruhi faktor eksternal yang memengaruhi persepsi konsumen akan sebuah produk, yang kemudian akan memengaruhi minat beli konsumen (Maoyan et al, 2014). Gunawan dan Huarng (2015) mengenukakan bahwa interaksi sosial dan resiko yang dipersepsikan melalui media sosial berpengaruh terhadap minat beli konsumen. Menurut Chih-Chin Liang dan Hanh Thi Dang (2015), komponen faktor perusahaan dan social and environmentalgroupmemengaruhi minat beli. Perceived ease of use, informasi produk, pengalaman media sosial, pengaruh sosial, dan perbedaan gender secara langsung memengaruhi pembelian online melalui media sosial. Oleh karena itu, Balakrishnan et.al, (2014) menganjurkan kepada pemasar untuk mengaplikasikan social media untuk mempromosikan produknya karena media sosial merupakan media pemasaran yang penting dalam menjangkau segmen pasar usia muda dengan cara lebih cepat dan efisien.

Metode Perusahaan menggunakan media sosial dengan maksud memasarkan produk atau jasanya, memberikan informasi tertentu kepada konsumen dan mempromosikan produk yang dihasilkannya. Media sosial digunakan sebagai alat komunikasi pemasaran untuk meningkatkan kesadaran konsumen terhadap produk, meningkatkan image produk, dan berakhir pada peningkatan penjualan (Kotler dan Keller, 2016). Minat beli merupakan suatu tindakan yang dilakukan konsumen sebelum mengambil keputusan pembelian suatu produk. Minat beli merupakan tahapan ketertarikan konsumen terhadap suatu produk dan minat beli muncul setelah adanya kesadaran dan persepsi konsumen terhadap produk tertentu. Menurut Maoyan et al (2014) dalam paradigma penelitiannya, minat beli dipengaruhi oleh media sosial yang dilakukan melalui persepsi konsumen terhadap produk.Secara teoris media sosial yang digunakan menjadi alat komunikasi yang penting dan memiliki peranan yang tinggi terhadap minat beli konsumen. Keterkaitan dua variabel tersebut dapat digambarkan dengan paradigma penelitian berikut (Gambar 1), di mana pengukuran sosial media berdasarkan teori Hauer (2014) dan minat beli diukur melalui model AIDA dimana tahap action tidak digunakan sebagai subvariabel karena action merupakan tindakan nyata konsumen dalam keputusan pembelian.

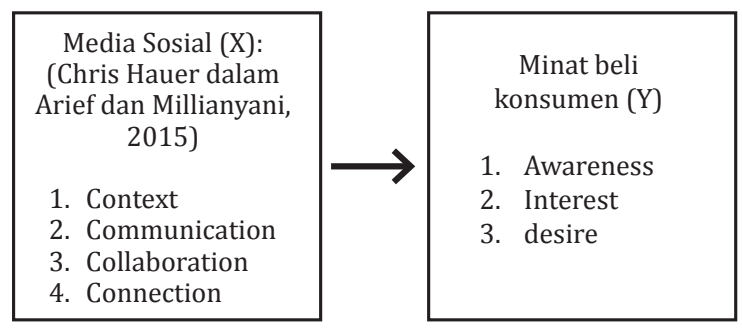

Gambar 1. Paradigma Penelitian

Pendekatan yang digunakan dalam penelitian adalah dengan pendekatan deskriptif dan verifikatif dengan metode kuantitatif yang telah disesuaikan dengan tujuan dan variabel penelitian. Penelitian ini memiliki tujuan untuk mengetahui apakah media sosial yang digunakan Floating Market berpengaruh terhadap minat beli konsumen atau wisatawan. Adapun objek penelitian yang diambil adalah mahasiswa karena instagram paling banyak digunakan oleh kalangan muda sepertiyang telah dipaparkan sebelumnya. Selain itu, kecenderungan anak muda yang senang bepergian dengan teman ke destinasi wisata menjadi alasan lain mengapa mahasiswa dijadikan objek dalam penelitian ini. Sampel penelitian adalah mahasiswa Universitas Padjadjaran di kota 
Bandung, Jawa Barat yang menggunakan aplikasi Instagram dikarenakan Universitas Padjadjaran memiliki mahasiswa dari berbagai daerah. Oleh sebab itu, mahasiswa Universitas Padjadjaran dianggap mampu untuk merepresentasikan minat kunjungan dari pengunjung Floating Market. Jumlah respondenyang digunakan 100 orang dengan error tolerance $10 \%$. Skala pengukuran yang digunakan dalam penelitian adalah dengan menggunakan skala Likert. Untuk melihat seberapa besar pengaruh media sosial instagram terhadap minat beli pengunjung Floating Market digunakan metode verifikatif berdasarkan data primer yang dilakukan. Ukuran yang digunakan adalah analisis regresi sederhana untuk mengetahui koefisien korelasi antara dua variabel yang diteliti. Penelitian ini bertujuan untuk meneliti bagaimanakah variabel independen (media sosial instagram) memengaruhi variabel dependen (minat beli), untuk menjawab tujuan penelitian tersebut adalah dengan menggunakan uji koefisien korelasi. Untuk menentukan kuatnya tingkat hubungan antara variabel X dan Y, maka dapat dilihat dari interval koefisien dan tingkat hubungan (Sugiyono, 2011).

\section{Hasil Penelitian dan Pembahasan}

Penilaian atas pengelolaan media instagram yang dilakukan oleh manajemen Floating Marketdilihat berdasarkan dimensi Context, Communication, Collaboration, dan Connection. Pengukuran minat beli diukur berdasarkan tingkat attention, desire, dan interest. Terakhir, data diolah untuk mengetahui hubungan dan pengaruh media sosial Instagram terrhadap minat beli konsumen Floating Market.

Pengukuran Context Instagram Floating Market, indikator yang digunakan dalam mengukur dimensi ini terdiri atas tiga indikator yaitu penggunaan bahasa, isi pesan, dan kelengkapan informasi. Tanggapan responden terhadap dimensi konteks termasuk dalam kategori baik yang menunjukkan bahwa konteks yang digunakan dalam media sosial Instagram Floating Market memiliki respon yang positif terutama terhadap kejelasan informasi dari foto yang digunakan. Pada dimensi Communication, penggunaan foto instagram menjadi variabel yang paling menarik perhatian konsumen terhadap Floating Market dibandingkan pesan text. Sedangkan pada variabel Collaboration, antusiasme pengunjung Floating Market untuk mem-posting foto di akun intagram pribadi cukup tinggi, namun tidak cukup kuat menarik minat responden untuk mem-follow akun resmi Instagram Floating Market.UntukConnection, konsumen tertarik untuk mengunjungi Floating Market ketika ada pemberitahuan event-event yang diselenggarakan di Floating Market melalui akun @floating.market.lembang

Minat beli responden atas Floating Market sudah tinggi, dapat dilihat dari respon atas komunikasi pemasaran termasuk yang dilakukan lewat media Instagramdi mana responden sebagian besar mengetahui keberadaan Floating Market (Attention). Tanggapan responden terhadap dimensi ketertarikan (Interest) termasuk dalam kategori "Cukup Baik" dikarenakan responden tertarik mengunjungi Floating Market tetapi tidak terlalu peduli dengan updatepada media Instagram mengenai informasi event-event yang diselenggarakan. Informasi yang didapatkan oleh konsumen mengenai Floating Market mempunyai dampak yang kuat terhadap keinginan (Desire) responden untuk merencanakan liburan ke Floating Market terutama saat berada di kota Bandung.

Dari hasil pengolahan data yang dilakukan, diketahui bahwa nilai korelasi antara media sosial instagram dengan minat beli sebesar 70.9\%. Nilai korelasi bertanda positif, yang berarti hubungan yang terjadi antara dua variabel adalah searah di mana 
semakin efektif media sosial instagram, maka semakin tinggi minat beli konsumen. Dari hasil pengolahan menggunakan SPSS didapatkan hasil nilai t-hitung sebesar 10,917 dengan alpha sebesar $10 \%$ dan derajat kebebasan $(\mathrm{dk})=\mathrm{n}-2$ yaitu $120-2$ $=118$, maka berdasarkan tabel distribusi $\mathrm{t}$ dua pihak, didapatkan hasil t-tabel sebesar 2.35837. Nilai t hitung $>\mathrm{t}$ tabel yaitu 10,227 $>2.35837$, maka pernyataan HO ditolak dan Ha diterima. Hal ini menunjukkan adanya pengaruh yang signifikan antara media sosial Instagram terhadap minat beli pengunjung Floating Market.

Tabel 1. Koefisien Determinasi

\begin{tabular}{|c|c|c|c|c|}
\hline \multicolumn{5}{|c|}{ Model Summary } \\
\hline Model & $\mathrm{R}$ & R Square & $\begin{array}{c}\text { Adjusted R } \\
\text { Square }\end{array}$ & $\begin{array}{l}\text { Std. Error of } \\
\text { the Estimate }\end{array}$ \\
\hline 1 & $.709^{\mathrm{a}}$ & .502 & .498 & 2.91269 \\
\hline
\end{tabular}

Berdasarkan pengolahan data koefisien korelasi sebesar $R=0.709$. Angka pada $R$ dalam tabel koefisien determinasi adalah angka yang menunjukkan kuatnya hubungan antara variabel X dan variabel Y. Secara deskriptif, menurut Sugiyono (2011:231), kuatnya pengaruh X terhadap Y berada pada tingkat kuat. Berdasarkan hasil pengolahan data, koefisien korelasi adalah 0.709, maka dapat dikategorikan bahwa pengaruh yang diberikan variabel instagram terhadap minat beli adalah pengaruh yang kuat. Selain itu, diperoleh koefisien determinasi: $\mathrm{R} 2=0.502=50,2 \% . \mathrm{R} 2$ adalah angka yang menunjukkan besarnya pengaruh variabel $\mathrm{X}$ terhadap variabel Y. Secara deskriptif, pengaruh $X$ terhadap $Y$ sebesar $50,2 \%$ dan sisanya $49.8 \%$ dipengaruhi oleh faktorfaktor lain diluar media sosial Instagram.

\section{Simpulan}

Hasil analisis deskriptif dan interpretasi data penelitian terhadap variabel media sosial Instagram menunjukkan bahwa komunikasi foto yang dikemas secara kreatif menjadi salah satu faktor yang cukup penting dalam menarik perhatian konsumen akan tempat tujuan wisata. Aplikasi media sosial Instagram yang menonjolkan sharing foto atau gambar terbukti punya korelasi kuat dalam memengaruhi minat beli konsumen.

\section{Daftar Pustaka}

Arief, Giri Maulana dan Heppy Millianyani. 2015. Pengaruh Social Media Marketing Melalui Instagram Terhadap Minat Beli Konsumen Sugar Tribe. Fakultas Ekonomi dan Bisnis Universitas Telkom.

Balea, Judith. 2016. The Latest Stats In Web And Mobile In Indonesia (Infographic). https:// www.techinasia.com diakses tanggal 29 Oktober 2016 dari https://www.techinasia. com/indonesia-web-mobile-statistics-we-are-social.

Bamini KPD Balakrsihnan, Mohd Irwan Dahnil, dan Wong Jiunn Yi.2014. "The Impact of Social Media Marketing Medium Toward Purchase Intention and Brand Loyalty Among Generation Y". Procedia - Social and Behavioral Sciences, 00 (2012) 000-000.

Ellya. 2015. Promosi Wisata Lebih Cepat Lewat Sosmed dan Media Sosial. http://beritajateng. net diakses tanggal 11 November 2016 pada jam 15.46 dari http://beritajateng.net/ promosi-wisata-lebih-cepat-lewat-sosmed-dan-media-sosial/. 
Gunawan, D. D., dan Huarng, K. 2015. “Viral effects of social network and media on consumers' purchase intention”. Journal of Business Research, 68(11), 2237-2241.

Kotler and Keller. 2016. Marketing Management. Pearson: Prentice hall

Kshetri, Anita and Bidyanand Jha. 2016. “Online Purchase Intention : A Study of Automobile Sector in India”. Rev. Integr. Bus. Econ. Res. Vol. 5 No.3, p.35-59.

Liang, Chih-Chin dan Hanh Thi Dang. 2015. "Factors influencing office-workers' purchase intention though social media : An empirical Study”. International Journal of Customer Relationship Marketing and Management (IJCRMM), 6(1), 1-16.

Madahi, Abdolrazagh dan Inda Sukati. 2012. "The Effect of External Factors on Purchase Intention Amongst Young Generation in Malaysia". International Business Research. Vol. 5 No.8, p. 153-159.

Maoyan et al. 2014. "Consumer Purchase Intention Research Based on Social Media Marketing”. International Journal of Business and Social Science. Vol. 5 No.10 (1), p. 92-97.

Negoro, Indra Hutami. 2015. http://www.kompasiana.com diakses pada tanggal 7 Desember 2016 dari http://www.kompasiana.com/ kutipankita/floating-market-muncul-di-pe rmukaan_565c54a2967a61720a55fa0a

Setiawan, Edhie Budi. 2015. "Quality and Purchase Intention Perceived Value towards Low Cost Energy-Saving Cars”. Jurnal Manajemen Transportasi \& Logistik. Vol. 02 No.01, p. 107-118.

Sugiyono. 2011. Statistika untuk Penelitian. Bandung: Alfabeta.

Van Vliet, Vincent. 2014. AIDA Model. http://www.toolshero.com diakses pada tanggal 4 November 2016 pada jam 21.15 dari http://www.toolshero.com/marketing/aidamodel/ 
